Dhaka Univ. J. Biol. Sci. 20(2): 109-115, 2011 (July)

\title{
PROXIMATE COMPOSITION OF DIFFERENT PORTION OF HILSA, TENUALOSA ILISHA FROM TWO REGIONS OF THE BAY OF BENGAL IN BANGLADESH
}

\author{
Md. Ali Hossain Shamim, Md. Kawser Ahmed* \\ and Abu Tareq Mohammad Abdullah ${ }^{1}$ \\ Department of Fisheries, University of Dhaka, Dhaka-1000, Bangladesh
}

Key words: Proximate composition, Ecosystem, The Bay of Bengal

\begin{abstract}
Tenualosa ilisha from Chittagong and Khulna regions of the Bay of Bengal was analyzed which showed that proximate compositions varied among the different portions of fish body. The highest value of moisture found in dorsal portion of the fish (Khulna region) whereas the lowest value of moisture found in caudal portion of the fish (Chittagong region) were 56.59 and $54.69 \%$, respectively. The protein content was estimated to be 20.56, 21.89, 20.29, 21.33, 20.87 and $20.50 \%$ in dorsal portion (Chittagong region), ventral portion (Chittagong region), caudal portion (Chittagong region), dorsal portion (Khulna region), ventral portion (Khulna region) and caudal portion (Khulna region), respectively. The fat content was recorded $18.66 \%$ in dorsal portion (Chittagong region), $20.28 \%$ in ventral portion (Chittagong region), $19.71 \%$ in caudal portion (Chittagong region), $18.65 \%$ in dorsal portion (Khulna region), 19.15\% in ventral portion (Khulna region) and $19.00 \%$ in caudal portion (Khulna region). The percentage of ash content was highest in ventral portion of fish body from the Khulna region (1.55) and lowest in dorsal portion of fish body from the Khulna region (1.03). The highest carbohydrate content was found in caudal portion of fish from the Chittagong region (3.93\%) and lowest in ventral portion of fish from the Chittagong region (1.60\%). The present findings revealed that the highest protein content was recorded as in ventral portion of fish from the Chittagong region $(21.89 \%)$ and the fat was highest in ventral portion of fish from the Chittagong region (20.28\%).
\end{abstract}

\section{Introduction}

Fishes are valuable sources of high quality protein and other organic products.(1) Fishes occupy significant position in the socio-economic fabric of the South Asian countries by providing the population not only the nutrition but also income and employment opportunities.(2)

Hilsa is an anadromous clupeoid fish occurs in the estuaries, brackish water lakes and fresh water rivers of the western division of the Indo-Pacific region. It grows and lives in sea and upstream to the rivers for breeding purpose. Hilsa, the national fish of

*Corresponding author: <kawser@univdhaka.edu>. ${ }^{1}$ Institute of Food Science and Technology (IFST), BCSIR, Dhaka-1205, Bangladesh. 
Bangladesh has been playing a very important role in our economy. Annual hilsa production is 2 lacks 90 thousands metric tons (2007 - 2008). Hilsa contributes about 13\% in the total fish production of the country. We earn Tk. 7000 core from hilsa fish export annually. It contributes in national GDP about 1\%.(3) Indian shad Tenualosa ilisha constitutes the largest single fishery of Bangladesh. Its annual catch accounts for nearly $40 \%$ of the total inland harvest of the country. ${ }^{(4)}$

The hilsa shad is largely an anadromous species, but two other ecotypes - a fluvial potamodromous type and a marine type - have been recognised. The potamodromous stocks appear to remain in the middle reaches of the rivers throughout the year and breed therein. The anadromous stocks, whose normal habitat is the lower region of the estuaries and the foreshore areas, ascend the rivers during the breeding season and return to the original habitat after spawning. The upstream migration during the main breeding season depends largely on the commencement of the south-west monsoon and consequent flooding of the major rivers of Bangladesh, Burma and India. Hilsa is valuable source of macro- and micronutrients and play an important role to provide essential nutrients for the people of Bangladesh.

Biochemical composition of fish flesh may vary within the same species of fish depending upon the fishing season, age, sex and habitat.(5) The variation is also found within the different region of the body.(6) In fishes, proximate composition means the composition of the fish flesh. Fish flesh contains four basic ingredients in varying proportions major nutrients such as water $(70-80 \%)$, protein $(18-20 \%)$, fat $(5 \%)$ and minerals $(5 \%)$ and minor nutrients such as vitamin, carbohydrate. (7) It has high nutritional value in terms of fats and proteins that are not commonly available in other foods.

Hilsa was once abundant in rivers, estuaries and marine area in Bangladesh. They were usually caught by a large number of subsistent fishermen. So it is essential to know the proximate composition of the fish. There are some information on the sensory, biochemical and bacteriological studies of hilsa.(8) The biochemical and nutritional studies of some fresh water fish species ${ }^{(9-11)}$ mentioned proximate composition of some commercial species of fresh water fish. Naser $e t$ al.(12) stated the proximate composition of shellfish (prawn and shrimp) in Bangladesh. Stansby ${ }^{(13)}$ has established that information on the chemical composition of fish in respect to the nutritive value is important to compare with other source of animal protein, meat and poultry products. There are a few reports on the nutritive values of hilsa. Hilsa is a migratory fish and it travels thousands of kilometers from upstream of river to mid ocean. Different regions of the Bay of Bengal contains different types of food (phyto- and zooplankton). Different types of food make proximate composition a bit different and also different part of the body makes the composition different as well. 
There is lack of information about the proximate composition of different portions of hilsa found in different regions of the Bay of Bengal. So, the aim of the present study was to determine the proximate composition of different portions of fish body from two regions of the Bay of Bengal.

\section{Materials and Methods}

The fresh fishes were collected from two different regions of the Bay of Bengal in Bangladesh i.e., as Chittagong and Khulna during February, 2009 (Figs. 1-2). Fishes were collected in early morning and after collection fish samples were taken in ice box, and as soon as possible to the Institute of Food Science \& Technology (IFST), BCSIR, Dhaka for analyses. After washing with tap water and taking length and weight of the fishes, the sample fish were frozen at $-18^{\circ} \mathrm{C}$ until laboratory analysis. Proximate composition of fish was determined by conventional method of AOAC (Association of Official Analytical Chemicals) on weight basis.(14)

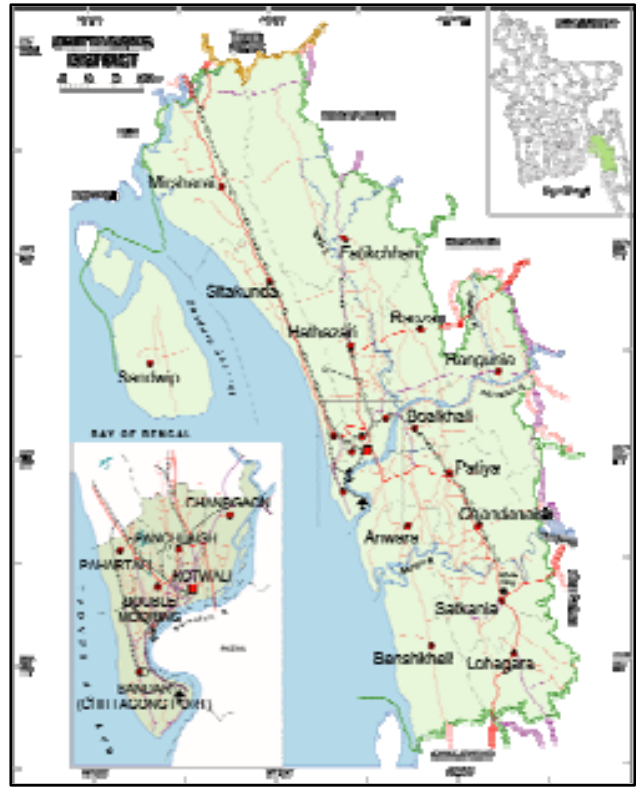

Fig. 1. Sample collection area (The Bay of Bengal, Chittagong).

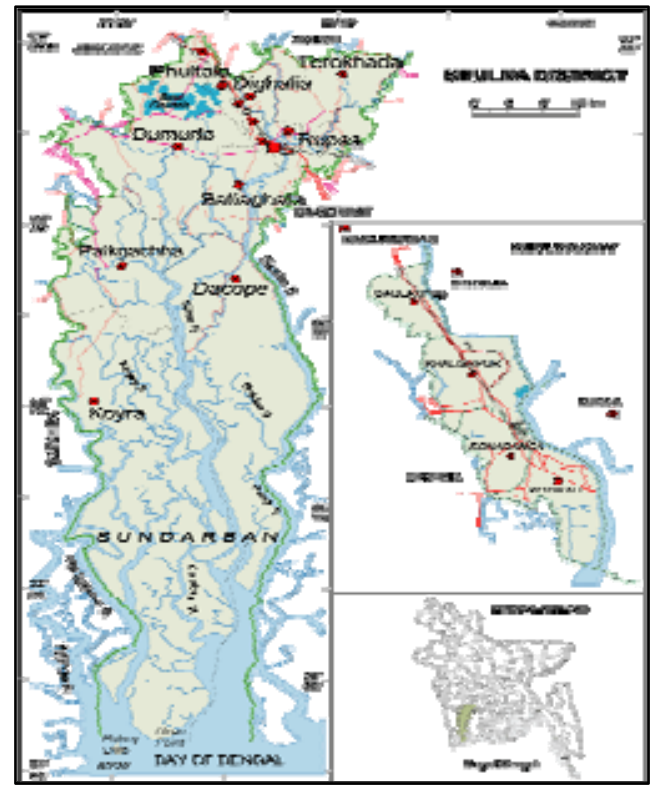

Fig. 2. Sample collection area (The Bay of Bengal, Khulna).

At first, the initial weights of the samples were taken. Then the fish sample was filleted. The samples were dried in an oven (Memmet $854 \mathrm{Schwabach}$ ) at about $105^{\circ} \mathrm{C}$ for about 8 to $10 \mathrm{hrs}$ until a constant weight was reached and cooled in a desiccator and weights of the samples were taken again. Then the samples were minced in an electric grinder. The percentage of moisture content was calculated by the following equation: 
Percentage of moisture $=($ Weight loses/original weight of sample $) \times 100$.

The protein content of the fish was determined by micro kjeldahl method. It involves conversion of organic nitrogen to ammonium sulphate by digestion with concentrated sulphuric acid in a microkjeldahl flask. ${ }^{(14)}$

For the estimation of fat content, the dried samples left after moisture determination were finely grinded and the fat was extracted with a nonpolar solvent, ethyl ether. After extraction, the solvent was evaporated and the extracted materials were weighed.(14)

The ash content of a sample is the residue left after ashing in a muffle furnace (Gerhardt) at about $550-600^{\circ} \mathrm{C}$ till the residue became white.

Data were analyzed by using SPSS version 16 for statistical programme with five per cent level of significance.

\section{Results and Discussion}

The major component of fish muscle is moisture. The moisture content varied from $54.69-56.59 \%$ (Fig. 3). The highest value was found in dorsal portion of the fish (Khulna region) whereas the lowest value was in caudal portion of the fish (Chittagong region). This result more or less coincides with the findings of Mansur et al. (8) in hilsa.

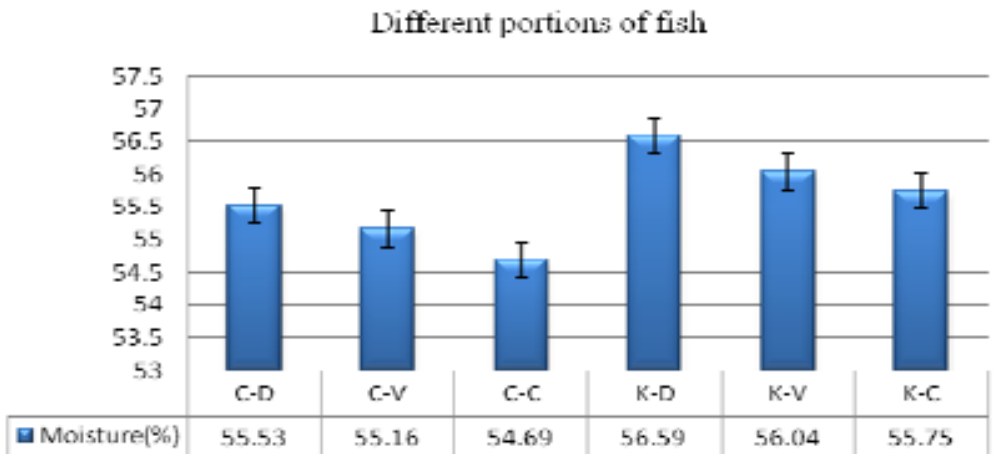

Fig. 3. Variation of moisture contents (\%) in different portions of fish. Moisture is significantly differed in the different portions of hilsa in same region (ANOVA, HSD; $\mathrm{p}<0.05$ ) but do not differ significantly (ANOVA, HSD; $\mathrm{p}>0.05$ ) in portion to portion in different regions. ${ }^{*} \mathrm{C}=$ Chittagong region of the Bay of Bengal, $\mathrm{K}=$ Khulna region of the Bay of Bengal, $\mathrm{D}=$ Dorsal portion, $\mathrm{V}=$ Ventral portion, $\mathrm{C}=$ Caudal portion, ${ }^{*}$ All are mean value $( \pm S E M)$.

The protein content was estimated as 20.56, 21.89, 20.29, 21.33, 20.87 and $20.50 \%$ in dorsal portion (Chittagong region), ventral portion (Chittagong region), caudal portion (Chittagong region), dorsal portion (Khulna region), ventral portion (Khulna region) and caudal portion (Khulna region), respectively (Fig. 4). The highest value was found in ventral portion (Chittagong region) and lowest value recorded in caudal portion (Chittagong region) of fish. 


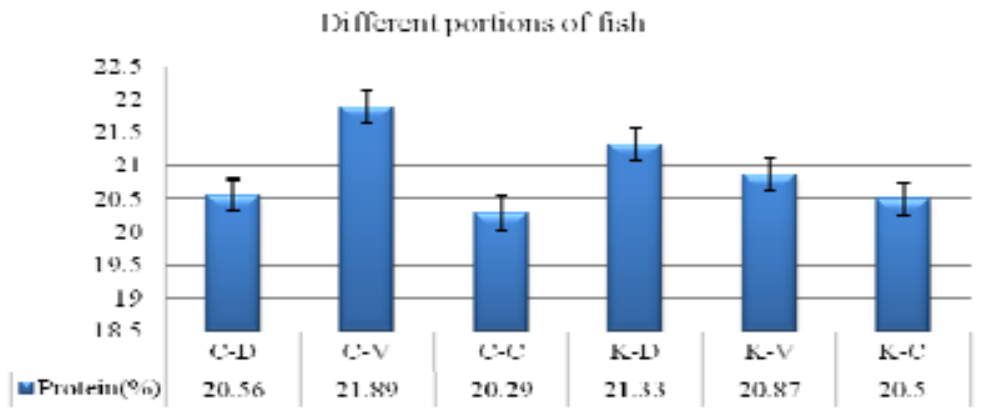

Fig. 4.Variation of protein contents (\%) in different portions of fish. Protein significantly differed in the different portion of hilsa in same region (ANOVA, HSD; $\mathrm{p}<0.05$ ) but do not differ significantly (ANOVA, HSD; $\mathrm{p}>0.05)$ in portions to portion in different regions. ${ }^{*} \mathrm{C}=$ Chittagong region of the Bay of Bengal, $\mathrm{K}=\mathrm{Khulna}$ region of the Bay of Bengal, $\mathrm{D}=$ Dorsal portion, $\mathrm{V}=$ Ventral portion, $\mathrm{C}=\mathrm{Caudal}$ portion, ${ }^{*} \mathrm{All}$ are mean value $( \pm$ SEM).

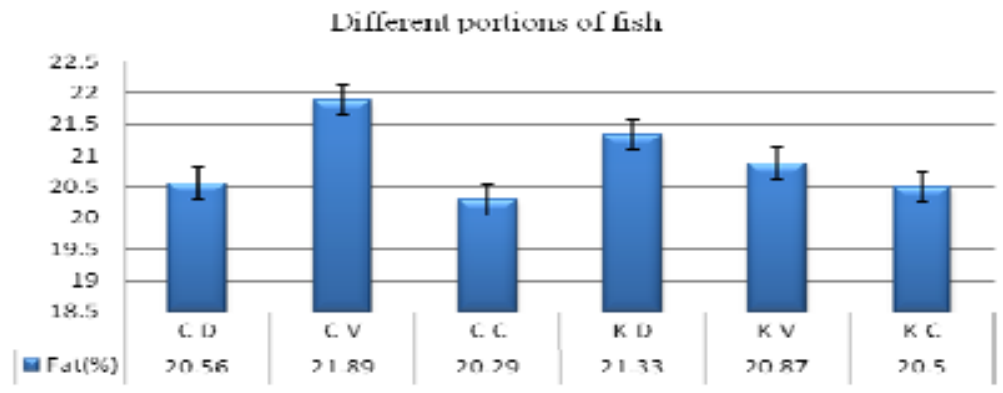

Fig. 5. Variation of fat contents (\%) in different portions of fish. Fat significantly differed in the different portions of hilsa in same region (ANOVA, HSD; $p<0.05$ ) but do not differ significantly (ANOVA, HSD; $p>$ 0.05) in portion to portion in different regions. ${ }^{*} \mathrm{C}=$ Chittagong region of the Bay of Bengal, $\mathrm{K}=\mathrm{Khulna}$ region of the Bay of Bengal, $\mathrm{D}=$ Dorsal portion, $\mathrm{V}=$ Ventral portion, $\mathrm{C}=$ Caudal portion, ${ }^{*}$ All are mean value $( \pm$ SEM).

The fat contents in different portions of fish body in different regions is shown in Fig. 5. The highest value of fat content was recorded in ventral portion of fish body from the Chittagong region $(20.28 \%$ ) and the lowest was in dorsal portion of fish body from the Khulna region (18.65\%). The fat content recorded 18.66, 19.71, 19.15 and $19.00 \%$ in dorsal portion (Chittagong region), caudal portion (Chittagong region), ventral portion (Khulna region) and caudal portion (Khulna region) respectively, was different to the result of Mansur et al. ${ }^{(8)}$ in hilsa (24.87\%) and might be due to habitat, season, age etc.

The highest ash content found in ventral portion of fish body from the Khulna region $(1.55 \%)$ and lowest in dorsal portion from the Khulna region $(1.03 \%$, Fig. 6$)$. The value of ash in dorsal portion (Chittagong region of the Bay of Bengal), ventral portion (Chittagong region), caudal portion (Chittagong region) and caudal portion (Khulna 
region) recorded as $1.31,1.05,1.35$ and $1.28 \%$, respectively was similar to the result of Mansur et al.(8)

The highest carbohydrate content found in caudal portion of fish body from the Chittagong region $(3.93 \%)$ and lowest in ventral portion of fish body from the Chittagong region (1.60\%, Fig. 7).

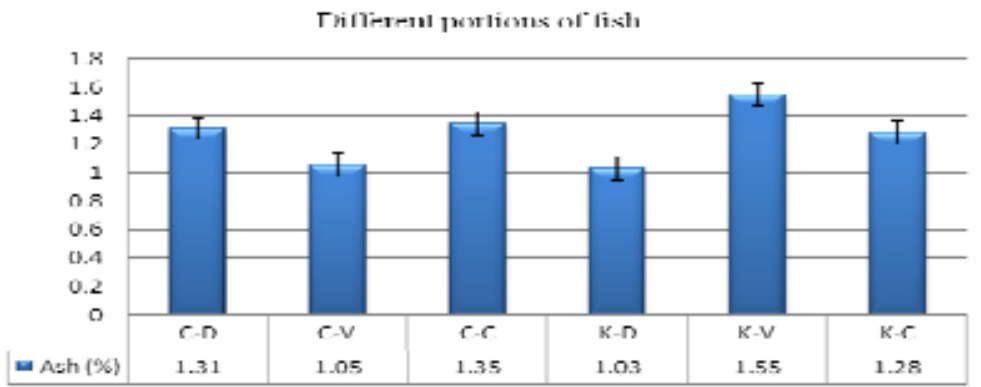

Fig. 6. Variation of ash contents (\%) in different portions of fish. Ash significantly differed in the different portions of hilsa in same region (ANOVA, HSD; $\mathrm{p}<0.05$ ) but do not differ significantly (ANOVA, HSD; $\mathrm{p}>$ 0.05) in portion to portion in different regions. ${ }^{*} \mathrm{C}=$ Chittagong region of the Bay of Bengal, $\mathrm{K}=\mathrm{Khulna}$ region of the Bay of Bengal, $\mathrm{D}=$ Dorsal portion, $\mathrm{V}=$ Ventral portion, $\mathrm{C}=\mathrm{Caudal}$ portion ${ }^{*}$ All are mean value $( \pm$ SEM).

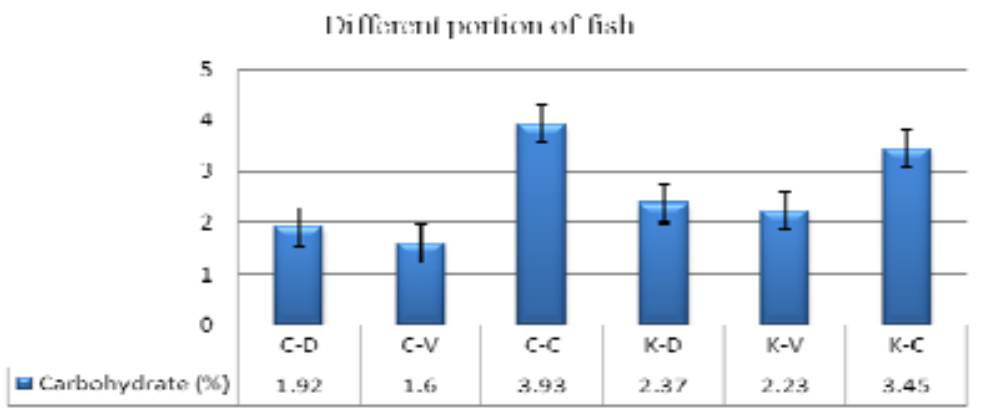

Fig. 7. Variation of carbohydrate contents (\%) in different portions of fish. Carbohydrate significantly differed in the different portions of hilsa in same region (ANOVA,HSD; $\mathrm{p}<0.05$ ) but do not differ significantly (ANOVA, HSD; $\mathrm{p}>0.05$ ) in portion to portion in different regions. ${ }^{*} \mathrm{C}=$ Chittagong region of the Bay of Bengal, $\mathrm{K}=$ Khulna region of the Bay of Bengal, $\mathrm{D}=$ Dorsal portion, $\mathrm{V}=$ Ventral portion, $\mathrm{C}=$ Caudal portion *All are mean value $( \pm \mathrm{SEM})$.

The result of the present investigation states the proximate composition of different portions of fish. However, variation in proximate composition of fish flesh may vary with different portions of fish body, species variation, season, age and the feeding habit of fish. ${ }^{(13,15,6)}$ The chemical composition of flesh may vary largely between and within species.(6) In the present study the differences of proximate composition may be due to the difference in different portion of fish body used (ANOVA, HSD; $\mathrm{p}<0.05$ ). 


\section{Acknowledgement}

Authors acknowledge the scientists and laboratory technicians of BCSIR Laboratories, Dhaka, Bangladesh for their technical support and continuous assistance to accomplish the present study.

\section{References}

1. Mc Cance RA and EM Widdowson 1960. Nutrition. Special Report No.297, Medical Research Council, London.

2. Rubbi SF, M Muslemuddin and MA Wahed 1978. The present status of fish technology and inspection of Bangladesh. Paper presented to the FAO/ DANIDA Workshop of Fish Technology, Colombo, Sri Lanka.

3. DoF (Department of Fisheries) 2009. Fisheries Fortnight (Matshya Pakkahaya in Bengali, Bangladesh). pp. 29.

4. Uddin M, MN Uddin and M Kamal 1998. Bull. Technol. Industri. Pangan. 9: 60-66.

5. Srivastava CBL 1985. A text book of fishery science and Indian fisheries, Kitab Mohal, Allahabad, India. pp. 47-86.

6. Jacquot R 1961. Organic constituent of fish and other aquatic animals. In: Fish as Food (Ed. Borgstrom, G.), Academic Press, New York and London. pp. 145-209.

7. Khurseed J and Mosharaff 1998. Seasonal changes on biochemical composition of fresh water murrel Ophiocephalus punctatus (Bloch). Hydrobiologia 32: 206-213.

8. Mansur MA, MA Sayed, SC Chakraborty, MN Uddin and MNA Khan 1998. Influence of spawning on the sensory, biochemical and bacteriological characters of dry salted hilsa(Hilsa ilisha) fish at ambient temperature. Bangladesh J. Fish. 21(1): 65-72.

9. Kamaluddin A, MA Malek and M Sanaullah 1977. Deshio khaddeer pustiman. Ins. Nutr. \& Fd. Sci. Dhaka University. pp. 1-20.

10. Gheyasuddin S, A Rahman and M Mumtazuddin 1979. Biochemical composition of Shell fishes of Bangladesh. Bangladesh J. Sci. Res. 2: 15-23.

11. Rubbi SF, M Mujibar, AR Khan, SS Jahan and M Begum 1987. Proximate composition and quality of some commercial species of fresh water fish. Bangladesh J. Sci. Res. 5(1): 1-20.

12. Naser MN, GW Chowdhury, MM Begum and W Haque 2007. Proximate composition of prawn, Macrobrachium rosenbergii and shrimp, Penaeus monodon. Dhaka Univ. J. Biol. Sci. 16(1): 61-66.

13. Stansby, MZ 1954. Composition of certain species of fresh water fish. Food. Res. 19: 231- 234.

14. AOAC (Association of Official Analytical Chemicals) 1995. Official Method of 12th edn. Association of official Analytical Chemists, Washington DC. pp. 832.

15. Salam MA, N Alam, M Nasiruddin, R Nabi and MZH Howlader 1995. Biochemical composition of body muscles and its caloric contents of tawes (Puntiu gonionotus, Bleeker). Bangladesh J. Sci. Res. 13(2): 205-211. 